\author{
ks. Piotr Morciniec ${ }^{1}$ \\ Uniwersytet Opolski
}

\title{
Starzeć się z godnością: od doświadczenia straty do owocowania
}

Podjęcie tytułowego problemu stanowi nie tylko wykonanie pewnego zadania badawczego, lecz jest równocześnie próbą zmierzenia się autora z perspektywą starości jako zadania egzystencjalnego. Chodzi o udzielenie odpowiedzi na pytanie: na ile mówienie o starości jest teoretyzowaniem, a w którym momencie staje się „moim tematem”? Jeżeli zgodzić się z niektórymi ujęciami problemu, to wczesna starość rozpoczyna się wraz z przekroczeniem półwiecza życia, a więc problematyzując konkretne zagadnienia z tej fazy życia, wchodzę w dyskusję z moim „tu i teraz”, weryfikuję moje dotychczasowe dojrzewanie do starości. Jest to więc w jakimś sensie osobisty dyskurs z sobą samym, udostępniony czytelnikowi.

Uderzające jest istnienie antagonistycznych wizji starości. Jedno ujęcie, biblijno-teologiczne, obecne m.in. w tekstach Pisma Świętego, zasad-

$1 \quad$ Piotr Morciniec, prof. dr hab., dyrektor Instytutu Nauk o Rodzinie oraz Kierownik Katedry Bioetyki i Etyki Społecznej Wydziału Teologicznego Uniwersytetu Opolskiego; redaktor naczelny międzynarodowego czasopisma „Family Forum”; obszary badawcze: biotyka i teologia moralna; ważniejsze publikacje i redakcje: Służba poczętemu życiu służba człowieczeństwu, Opole 1993; Etyczne aspekty transplantacyjnej terapii chorób neurozwyrodnieniowych. Studium teologicznomoralne, Opole 2000; Ocalić obraz człowieka. Antropologiczne podstawy moralności, Opole 2003; Wyjazdy zarobkowe - szansa czy zagrożenie? Perspektywa społeczno-moralna, Opole 2005; Bioetyka personalistyczna wobec zwłok ludzkich, Opole 2009; Zniewoleni działaniem. Uzależnienia behawioralne a rodzina, Opole 2013. 
niczo pozytywnie ukazuje starość ${ }^{2}$, nawet jeżeli nie brakuje tam fragmentów głęboko realistycznych, z cierpieniem i umieraniem jako fazą życia. Nie należy jednak, jak się wydaje, ograniczać tej teologicznej perspektywy wyłącznie do wizji wiecznej szczęśliwości, która „wszystko staremu człowiekowi wynagrodzi”, gdyż przesłanie biblijne stara się wydobyć także dobro życia ziemskiego. W drugim ujęciu - nazwijmy je socjokulturowym - wybrzmiewają tony generalnie pesymistyczne, podobnie jak w poetyckim ujęciu starości w piosence Edyty Geppert o landrynkach ${ }^{3}$. Zwłaszcza w opisach kulturowych i socjologicznych ostatnich wieków w spojrzeniu na sytuację egzystencjalną seniorów trudno znaleźć choćby pojedyncze elementy pozytywne. Fundamentalne pytania brzmią: które z tych ujęć jest prawdziwe? I czy da się te dwie perspektywy połączyć? Z pytań tych wynikają kolejne: czy różnica podejścia wynika wyłącznie z odmienności światopoglądowej obu ujęć, a optymistycznie widzimy, tylko patrząc „oczyma wiary”? Wydaje się, że nie. Gdzie więc jest przejście między tymi dwiema perspektywami?

Na pytanie o podmiot, który może pomóc osobom starszym, jedna z dojrzałych wiekowo rozmówczyń odpowiedziała: „my sami”. Ta krótka odpowiedź bardzo trafnie wprowadza w zagadnienie starzenia się z godnością. To jest bowiem podstawowe przesłanie dotyczące godnego starzenia się: jakość starości zależy od osoby, która ją przeżywa lub świadomie zamierza przeżyć. Ale równocześnie nie jest to prawda tak oczywista, skoro wystarczy sięgnąć do historii XX wieku, aby odkryć, że jeszcze w jego pierwszej połowie człowiek stary traktowany był jako „przedmiot tro-

2 Rozwinięcie tezy zob. np.J. Dziedzic, Das Alter - ein Problem oder eine Chance? Versuch einer multiperspektivischen pastoralen Reflexion, „Analecta Cracoviensia” 2011, t. 43, s. 33-36. „Spóźnili się na pociąg świata | odtąd czekają | jak z bicza trzasł przemknęły lata | czas w miejscu stanął | W gazetach krzyży rośnie rząd | nad kolegami | przed wojną to w szwach pękał dom | a teraz sami | Landrynek przechowują stos | w starym bufecie | opowiadają wszystkim w krąg lo dobrych dzieciach | Tyle by mieli przecież im | do po milczenia |i w głowie nie postanie myśl | że czas to pieniądz | Daremnie wzrok wbijają w drzwi | tuląc w objęciach | tych, co znów nie zdążyli przyjść | - wnuki na zdjęciach | Gdy wreszcie w pustych stanie drzwiach | zła Czarna Pani | to poczęstują, żaden strach | ją landrynkami...". Edyta Geppert, Landrynki, www.tekstowo.pl/piosenka,edyta_geppert,landrynki. html (21.06.2014). 
ski” w znaczeniu: „co z nim można zrobić”. Swoista - dodajmy: nieludzka - „instrukcja obsługi” (dla) starego człowieka brzmiała: należy wycofać się z życia, nie stawać na przeszkodzie, nie narzekać i cierpieć, czekając na śmierć. Dopiero perspektywa praw człowieka, których stary człowiek przecież nie jest pozbawiony, doprowadziła do zmiany postrzegania i stary człowiek został odkryty jako podmiot. Ale żeby tę zmianę zobaczyć, przyjrzyjmy się najpierw samej starości i temu, co się w niej dzieje, aby następnie spróbować odpowiedzieć na pytanie, co możemy zrobić jako ludzie, których starość albo już zaskoczyła, albo najprawdopodobniej w przyszłości zaskoczy.

Wracając do podstawowego pytania o możliwość spotkania się socjokulturowej i biblijno-teologicznej wizji starości - wydaje się, że odpowiedź na nie może być pozytywna, ale pod pewnymi warunkami. Moim zdaniem w patrzeniu na wiek senioralny dość gremialnie pomijamy pewien krok, który albo zakładamy, albo uważamy za oczywisty. W konsekwencji następuje dezintegracja całego procesu przeżywania starości. Zidentyfikujmy więc ten „brakujący element”.

W przypadku zmian związanych z kolejnymi etapami życia człowieka przyzwyczailiśmy się do mówienia o „stratach rozwojowych”. Okazuje się jednak, że o ile we wszystkich wcześniejszych etapach zasadniczo mamy do czynienia z rzeczywistym rozwojem, o tyle ostatnie fazy życia zdają się takiej tezie zaprzeczać. Trudno oprzeć się wrażeniu, iż mamy do czynienia z formą psychologicznej manipulacji, kiedy sugeruje się seniorom, że doświadczają strat rozwojowych, kiedy ów „rozwój” ma wszystkie cechy uwstecznienia i redukcji. Gdyby to rzeczywiście był automatyczny rozwój, to nie wiązałyby się z nim szczególne dodatkowe zadania, skoro jednak chodzi o zanik (uwstecznienie), to pojawiają się nowe wyzwania, wymagające celowej aktywności ze strony samych zainteresowanych. A wystarczy dokładniej przeanalizować czas życia zwany starością, okresem senioralnym, emeryturą, aby stwierdzić ponad wszelką wątpliwość, że otwiera go długa lista strat, a więc wartości, które osoba traci lub z których jest zmuszona zrezygnować. Wspólne ich imię to „przemijanie", które notabene wprost zaliczane jest do strat znaczących. Ten fakt należy koniecznie uwzględnić we wszelkich postulatach formułowanych pod adresem ludzi starych. 
Oto przykładowa lista strat pojawiających się jako kontinuum w życiu senioralnym: odchodzą bliscy nam ludzie, tak że z krewnymi i przyjaciółmi najczęściej spotykamy się na pogrzebach, aż któregoś dniach ich samych odprowadzamy na ostatni spoczynek. Słabnie zdrowie i trudno nie nazwać tego faktu ewidentną stratą. Już nie ta krzepa, nie ta kondycja, i to niezależnie od starań podejmowanych dla utrzymania dobrej formy. Nawet przekaz medialny stara się ten fakt umiejętnie omijać i w wirtualnych seniorach rzadko odkrywamy swoją kondycję zdrowotną i niekoniecznie młodzieńczą fantazję. Spojrzenie w lustro uświadamia nieubłagany upływ czasu, który poorał twarz zmarszczkami, przybielił włosy, uwypuklił niedomogi - nawet najlepsze osiągnięcia kosmetyczne nie są w stanie odmłodzić emeryta. Tylko czasem w akcie desperacji lub protestu „młodzież senioralna” wkłada mini, prowokacyjnie się maluje, budząc raczej litość niż podziw. Jest to jednak swoisty wyraz buntu przeciw starzeniu się, przeciw niedogodnościom starości. Także upragniona przez dziesięciolecia pracy emerytura, konieczność oddania swojego stanowiska młodszym i sprawniejszym powoduje odstawienie na boczny tor życia i często okazuje się finansową katastrofą. Jakby tego było mało, choroba, ból i ograniczenia przychodzą w sposób nieunikniony, nie pytając o pozwolenie. Lekarz, często dotąd nieznany, staje się najczęściej odwiedzanym znajomym.

Czy na czas starości i powolnego odchodzenia nie ma innego scenariusza, jak tylko jęk Hioba i wołanie z krzyża: „Boże mój [...] czemuś mnie opuścił"? Ktoś może zapytać, po co o tym mówić, skoro przynajmniej większość z nas albo już przez te stany przechodziła, albo jest na ich pograniczu. Odpowiedź jest tak banalna, że - moim zdaniem - stanowczo za mało uświadomiona. Wystarczy poczytać niemałą część publikacji na temat starości czy dokumentów i opracowań duszpasterskich z tego zakresu, aby natknąć się na instruktarz techniczny, jak należy właściwie przeżyć starość. Okazuje się jednak, że godnego lub - używając wymowniejszego terminu - owocnego, czyli wiążącego się z owocowaniem, przeżycia starości nie da się skutecznie nakazać. Jest to więc co najwyżej marnotrawienie słów.

Gdzie więc znajduje się właściwa droga przejścia między tytułowymi wielkościami? Otóż okres senioralny jako czas odnajdywania nowego 
sensu można tylko w y br ać, nie zalecić lub nakazać, a to wiąże się najpierw z uświadomieniem sobie swojego aktualnego stanu (1), następnie z przepracowaniem zdiagnozowanych strat rzeczywistych i subiektywnych, czasem nawet urojonych (2), by dopiero w trakcie celowego procesu dojść do zbierania owoców życia i starości (3) i do próby praktycznej realizacji takiego podejścia (4). Przynajmniej na tropie takiego rozumienia życia znajdują się seniorzy, którzy - jak mój mistrz naukowy, prof. Ginter Virt $^{4}$ - mówią i piszą o potrzebie przygotowania się do godnej starości. Nawiasem mówiąc, w odniesieniu do jesieni życia najczęstszym jest postulat, bystarzeć się z godnością.

\section{Opis stanu faktycznego}

Starzenie się jest niewątpliwie wieloaspektowym procesem, który nie daje się zredukować do jednej, a nawet do kilku przyczyn. Nic więc dziwnego, że sformułowano tak wiele teorii dotyczących procesu starzenia się. Uderza jednak fakt, że wciąż do głosu dochodziła pokusa wskazania przyczyny decydującej - od starożytności z artystotelesowskim wewnętrznym ochłodzeniem organizmu, utratą równowagi cieczy u Hipokratesa czy samozatrucia organizmu u Paracelsusa. Prawdą jest jednak także, że procesy starcze organizmu są złożone i całościowe, jak sam człowiek jest bytem wielopłaszczyznowym. Przy wielu podobieństwach na poziomach zewnętrznym i wewnętrznym starzenie się jest procesem indywidualnym, co oznacza, że dokonuje się zawsze w odniesieniu do danej osoby.

Zamierzając z perspektywy bioetycznej przyjrzeć się temu fenomenowi, musimy najpierw dokonać pojęciowego zdefiniowania (wyznaczenia granic) i rozróżnienia, czym zamierzamy się zająć. Posiłkując się określeniem jednego ze specjalistów ${ }^{5}$, opisowo możemy zdefiniować starość jako okres życia po zakończeniu aktywności zawodowej i opieki nad własnymi

${ }^{4}$ G. Virt, Sich auf das Alter einstellen solange noch Zeit ist, „Family Forum“ (2001) 1, s. 179-192.

5 Szeroko zob. P. Laslett, Das dritte Alter, München 1995. 
dziećmi, charakteryzujący się zredukowaniem obowiązków, który - przynajmniej w dwudziestowiecznym (zachodnio)europejskim kręgu kulturowym - charakteryzuje się statystycznie rosnącym dobrobytem przy równoczesnym, przynajmniej częściowym, zmniejszaniu się troski materialnej i opieki rodzinnej nad seniorami. Wspomniana redukcja obowiązków zawodowych i rodzinnych oznacza, że pojawia się specyficzny n a dmiar wolnego czas u oraz że nadszedł czas, aby zająć się sobą, po bardzo dotąd absorbującej fazie rodzicielstwa z wszystkimi opisanymi syndromami, np. matki Polki. Statystyczna poprawa sytuacji nie pozwala przemilczeć faktu, że równocześnie w grupie osób starszych obserwuje się narastanie obszarów nowej biedy, związane z załamaniem się emerytalnych systemów solidarnościowych, wynikającym m.in. z kryzysu demograficznego ${ }^{6}$.

W przypadku osób starszych dwie trzecie lub trzy czwarte ich życia (w zależności od liczby wyodrębnianych faz) stało się już rzeczywistością i zarys danych biograficznych wydaje się spetryfikowany. Oznacza to równocześnie, że jedna trzecia lub jedna czwarta życia stanowi możliwość i szansę, ale niewątpliwie po spełnieniu pewnych istotnych wymogów. Przywołując amerykańskie żartobliwe określenie, należy w nadchodzącym etapie życia rozróżnić jeszcze fazy: go-goes, slow goes i no goes. W tej ostatniej części życia stanowczo nie chodzi o zachowanie status quo, czyli kontynuowanie tego, co było dotąd, lecz o nauczenie się i sięgnięcie do obszarów nowych doświadczeń, nowe wartościowanie i nowe rozwiązania dotyczące fundamentalnych pytań o sens i o cel życia. Pluralizm współczesny, stawiający na wolność społeczną, gospodarczą i indywidualną, pozwala także na wypróbowanie i realizację nowych form życia przez starzejące się osoby. Podarowane dodatkowe lata wymagają więc kultywowania. Każdy ze wspomnianych aspektów nowego kształtowania życia seniora wymaga świadomego wyboru i współdziałania, w którym jednak najczęściej nie sprawdzają się stare modele zachowań. Stąd pojawia

Na ten problem zwraca się uwagę także na poziomie Unii Europejskiej (Parlament Europejski). Omówienie zob. np. G. Ancyparowicz, Kapitałowe emerytury i renty a ryzyko ubóstwa w Polsce, [w:] Rządowa Rada Ludnościowa, O sytuacji ludzi starszych, red. J. Hrynkiewicz, Warszawa 2012, s. 89. 
się konieczność odpowiedzenia sobie przez seniora czy seniorkę na pytanie, jak pielęgnować dany i zadany nowy okres życia. I to jest niewątpliwie pytanie (bio)etyczne ${ }^{7}$.

Warto sobie uświadomić, że (bio)etyka - jako nauka normatywna (filozoficzna i teologiczna) o ludzkich działaniach i postawach rozróżnianych jako dobre-złe, godziwe-niegodziwe - jest fenomenem kryzysowym („,kołem ratunkowym”), który uaktywnia się wtedy, kiedy moralność z jakiegoś powodu znajduje się w kryzysie. Moralność stanowi zbiór najczęściej niereflektowanych reguł, norm i postaw, które prowadzą zazwyczaj do podejmowania działań rutynowych, a więc stanowią pewne dobre przyzwyczajenia (nawyki). Co może doprowadzić do jej kryzysu? W interesującym nas kontekście mogą to być m.in. braki w wykształceniu, konkurencyjne normy pojawiające się w pluralistycznym społeczeństwie, ale najbardziej chyba pojawienie się nowych problemów, dla których nie mamy jeszcze „wytrenowanych" reguł i schematów dobrych zachowań ${ }^{8}$. Nic więc dziwnego, że w przypadku bioetyki definicyjnie mówimy o konstruowaniu rozstrzygnięć normatywnych w sytuacjach granicznych. Spotkanie z własną starością jest taką właśnie sytuacją graniczną o cechach opisanych powyżej.

Do przedstawionego opisu starości należy dodać osób starszych obraz samych siebie oraz ich obraz komunikowany na różne sposoby przez innych członków społeczeństwa, które to obrazy razem funkcjonują w bardzo ścisłej współzależności. Kolejnym komponentem jest docenienie lub lekceważenie osób starych w społeczeństwie (raz są szczególnie poszukiwaną grupą społeczną, np. w reklamie, innym razem ciężarem dla społeczeństwa), przy czym społeczne tolerowanie seniorów nie jest szczytem pozytywnego nastawienia. Od tych wszystkich dynamizmów w dużej mierze zależy samoocena osób starszych. Ta z kolei generuje wiele kolejnych strat (np. narastające depresje, choroby i cierpienia psychiczne) lub daje siłę do przepracowania wartości utraconych.

Por. G. Virt, Sich auf das Alter einstellen solange noch Zeit ist, dz. cyt., s. 181.

8 G. Virt, Die Bedeutung der Ethikberatung für einschlägige EU-regelungen. Zur Rolle des theologischen Ethikers in einem säkularisierten Europa, Laibach 2013, mps, s. 4. 


\section{ks. Piotr Morciniec}

Nic więc dziwnego, że greckie słowo krisis wydaje się właściwym określeniem na integralne opisanie tego, co dzieje się wraz ze zbliżaniem się do ostatniej tercji lub kwarty życia. Strata (właściwie rozumiana) jest zawsze związana z kryzysem, który jest nieodłącznym elementem życia ludzkiego. Współczesny świat nadał pojęciu „kryzys” jednoznacznie pejoratywne znaczenie, jednak jego grecka etymologia nie wskazuje na wyłącznie negatywny wymiar. W Słownikujęzyka polskiego Jana Kopalińskiego „kryzys” opisano jako „moment, okres przełomu, przesilenie, decydujący zwrot" ". Strata i kryzys stanowią dwa ujęcia jednej rzeczywistości. Pozornie brak w nich nadziei, zdają się przekreślać sens życia człowieka, jego rolę i znaczenie w świecie. Wydaje się jednak, że istotną dla kryzysu ambiwalencję właściwie oddaje dopiero przeżywanie straty w postaci żałoby ${ }^{10}$, o czym będzie mowa poniżej.

\section{Przepracowanie strat}

Jakjuż wspomniałem, w analizowanym kontekście jednym z największych - moim zdaniem - błędów, jakie popełniamy w odniesieniu do osób starszych, jest poprzestanie na moralizowaniu, czyli na instrukcji, co seniorzy powinni zrobić, bez uwzględnienia punktu wyjścia, w którym się oni znajdują. Tym punktem wyjścia jest doświadczenie nagromadzenia strat, które domagają się przepracowania. A przecież miarą sensu życia współczesnego człowieka - niezależnie od wieku - wydaje się sukces, który trudno pogodzić ze stratą. Mimo iż doświadczenie strat wpisane jest w życie człowieka i stanowi jakościowe kryterium jego dojrzałości ${ }^{11}$, rzadko postrzegane jest jako szansa wewnętrznego rozwoju. Strata bowiem generalnie kojarzona jest z bólem i cierpie-

9 W. Kopaliński, Słownik wyrazów obcych, Warszawa 2007, s. 285.

10 Żałobę wprost jako sytuację kryzysową, w której w wyniku utraty znaczącej wartości (osoby) rozpada się część osobistego oraz społecznego świata człowieka, definiują w liście biskupi niemieccy. Die Deutschen Bischöfe, Tote begraben und Trauernde trösten. Bestattungskultur im Wandel aus katholischer Sicht, Bonn 2005, s. 32. Szerzej zob. L. Kroll, Towarzyszenie w żałobie jako postulat etyczny. Studium teologicznomoralne, Opole 2006, mps, s. 48-58.

11 Por. K. Grzywocz, Jak przeżyć stratę, „Zeszyty Formacji Duchowej” (2004) 24, s. 30. 
niem, a te budzą lęk, niepokój, chęć ucieczki. Właściwą drogą przejścia przez stratę jest droga żałoby, którą prawdopodobnie większość z nas (także starszych) definitywnie kojarzy z czym innym niż z własną sytuacją życiową.

Powtórzmy więc, żałoba jest drogą przepracowania wszelkich strat, także przemijania. Wyrażanie żalu nie jest oznaką słabości, niedojrzałości, nieumiejętności kontrolowania w pełni swoich emocji, lecz głęboką ludzką potrzebą zareagowania na stratę kogoś lub czegoś dla nas znaczącego $^{12}$. Bez względu na wiek czy doświadczenia życiowe żal po stracie pełni generalnie funkcje pozytywne. Żałoba jest bowiem nie tylko wyrażeniem sprzecznych uczuć, które generuje strata, lecz kształtowaniem na nowo całego życia człowieka: myśli, świadomości, światopoglądu, życiowych celów, relacji do siebie i innych ludzi ${ }^{13}$. Jak się okazuje, tego także potrzebujemy, wchodząc w nową fazę życia, zwaną starością.

Żałoba nie jest chorobą, lecz normalną reakcją na sytuację utraty, przy czym jej normalność jest bardzo złożona i trudna. W procesie żałoby jest zawarte zarówno zagrożenie (wywołanie poważnych trwałych zaburzeń, które uniemożliwią prawidłowe funkcjonowanie jednostki, w naszym przypadku osoby starszej), jak i szansa (wejście na wyższy poziom wewnętrznego rozwoju, życie z większą świadomością rzeczy najważniejszych). Każda strata wiąże się z żałobą. Kto doświadczył straty, doświadcza także żalu i żałoby z nią związanej. „Reakcja żałoby jest normalnym i bolesnym stanem emocjonalnym, który następuje po stracie. [...] Wspomagana praca nad żalem po stracie obejmuje wyrażenie emocji, zrozumienie znaczenia utraconej osoby lub obiektu, wyjaśnienie ambiwalencji w danej relacji i ostatecznie zdolność do zaufania i miłości..."14. Straty nie można ze swego życia wykluczyć, nie można przed nią uciec, ale można ją umiejętnie przeżyć.

Kryzys, jakim jest zespół strat zwany starzeniem się, stanowi szansę rozwoju, dokonania (prawdopodobnie po raz ostatni) konstruktywnych

12 Por. H. Feifel, Psychologia a śmierć, [w:] Psychologiczne aspekty śmierci, umierania i żałoby, red. W. Badura-Madej, Kraków 1993, s. 15.

13 Por. Ch. Paul, Wie kann ich mit meiner Trauer leben?, Gütersloh 2000, s. 7.

14 F. M. Ochberg, Post-traumatic therapy and victims of violence, New York 1988, s. 10. 
zmian w swoim życiu, ale jest to jedynie szansa. Przejście przez kryzys, zazwyczaj bardzo bolesne, pełne lęków, smutku, własnej bezradności i niepewności, a także poczucia winy, krzywdy i gniewu, może jednak wyzwolić drzemiący w człowieku ,potencjał człowieczeństwa”, dotykając także towarzyszących mu osób. Nic jednak dziwnego, że starość bywa także definiowana jako czas narastającej depresji, pewnego zagubienia się, i nie jest to spowodowane tylko psychiką ludzi starszych, lecz także wieloma negatywnymi emocjami targającymi seniorami, które mają swoje źródło w doświadczanych stratach. Dlatego aby móc osiągnąć to, co naprawdę wartościowe w starości, by być gotowym do konfrontacji z tym, co nieznane, a co przyniesie przyszłość, płaci się własnym cierpieniem, które w ostateczności ma doprowadzić do przemiany straty w świadome oddanie ${ }^{15}$.

Verena Kast postrzega żałobę jako swoisty proces rozwojowy, któremu towarzyszy wielość emocji i przeżyć, których doświadczenie stanowi szansę zrozumienia na nowo siebie oraz świata, przejście od tożsamości będącej efektem określonej relacji do tożsamości w pełni indywidualnej. Przeżyć żałobę to znaczy pozwolić odejść (temu, co było wcześniej, co było dla mnie wartością), to zrozumieć, że wszystko to, co wspólnie wzrastało i wzrosło w związku, jest zakończone, że trzeba wzrosnąć na nowo, na własnych korzeniach, gdyż każdy człowiek musi także umieć być sam dla siebie ${ }^{16}$.

W kontekście strat związanych ze starością pojawia się jeden istotny dodatkowy czynnik, mianowicie wi elość strat, z którymi konfrontowany jest senior, która sprawia, że nie brakuje głosów, iż tych strat nie da się przepracować. Moim zdaniem, jeżeli podejmie się wyzwanie przepracowania najbardziej podstawowych z doświadczonych strat, to jesteśmy w stanie odnaleźć się w nowych realiach. Rzecz jasna narzuca się pytanie, przy pomocy jakich narzędzi ludzie starsi mogą sobie pomóc w optymalnym kształtowaniu swojej starości naznaczonej stratami? Okazuje się, że takiego narzędzia dostarcza antropologia personalistycz-

15 Por. L. Kroll, Towarzyszenie w żałobie jako postulat etyczny..., dz. cyt., s. 57.

16 Por. V. Kast, Kryzys jest szansa, czyli jak wykorzystać trudności, tłum. R. Zajączkowski, Kielce 2001, s. 45-46; V. Kast, Sich einlassen und loslassen, Freiburg i. Br. 1994, s. 9. 
na, czyli konkretna koncepcja człowieka. Jeżeli człowiek od pierwszych chwil swego istnienia aż do naturalnej śmierci jest takim samym człowiekiem, z tą samą godnością osobową, z tymi samymi możliwościami życiowymi, to odkrywamy w człowieku wymiar, który nazywa się działaniem podmiotowym, a opisuje zwrotami: „co ja robię”, „, „o ja mogę lub powinienem zrobić". Warto zwrócić uwagę, że w mówieniu o starości częściej używa się innej formy: „co się z tym starym człowiekiem dzieje" i taka forma jest n i l lu d zka, bo nieprzystająca do człowieka jako osoby, która o sobie stanowi - „coś dzieje się” z przedmiotem. Podmiot bierze życie w swoje ręce.

Jeżeli senior ma świadomość przemijania i bierze sprawy w swoje ręce, to będzie odkrywał pewne zadania, po których wypełnieniu staje przed nowym pięknem swojego życia tu i teraz. Podstawowa różnica polega na tym, że jeżeli zabierają mi jakieś cenne dla mnie dobra - jestem w roli przedmiotu, którym ktoś z zewnątrz kieruje - rodzi się we mnie bunt, rozgoryczenie; jeżeli sam świadomie oddaję, rozumiejąc lub przynajmniej zgadzając się z koniecznością takiego kroku, oddane wartości w jakiś inny sposób pozostają ze mną i rodzą się pozytywne emocje. Tak funkcjonuje przedmiotowe lub podmiotowe podejście do własnego przemijania. Postawa „coś się ze mną dzieje” rodzi bezsilność i spycha w depresję, postawa porządkowania własnego życia w obliczu wyższej konieczności zwanej przemijaniem, starzeniem się potwierdza moją wartość i godność osoby kompetentnej w swoich decyzjach. Starość wtedy staje się starością godnie przeżywaną, kiedy straty nie wyznaczają mi scenariusza życia, tylko są zakończeniem pewnego etapu, który otwiera mnie równocześnie na etap nowy.

W tym kontekście warto zacytować św. Jana Pawła II, który pisząc w 1999 roku do swoich „starych Braci i Sióstr w człowieczeństwie”, sam już wtedy wiekowy i mocno schorowany, wyznał ${ }^{17}$ :

Życząc wam w tym duchu, drodzy Bracia i Siostry w podeszłym wieku, abyście pogodnie przeżywali lata, które Bóg przeznaczył każdemu z was, pragnę zarazem bardzo otwarcie podzielić się z wami uczuciami, jakich doznaję u schyłku mego

17 Jan Paweł II, List Do moich Braci i Sióstr - ludzi w podeszłym wieku, Watykan 1999, 17. 
życia [...]. Mimo ograniczeń mego wieku bardzo wysoko cenię sobie życie i umiem się nim cieszyć. Dziękuję za to Bogu! Pięknie jest służyć aż do końca sprawie Królestwa Bożego [podkreśl. P.M.].

I od razu dodał: „Zarazem jednak głębokim pokojem napełnia mnie myśl o chwili, w której Bóg wezwie mnie do siebie - z życia do życia!”

Papieżjawi się w swoim wyznaniu jako człowiek stary, który przepracował najistotniejsze straty i potrafił odkryć nowe piękno swojej egzystencji.

Szukając koncepcji psychologicznej przepracowania strat właśnie w takim personalistycznym duchu, chciałbym zaproponować ujęcie Jamesa Williama Wordena ${ }^{18}$, który - inaczej niż wielu autorów - nie dzieli procesu żałoby na kolejne fazy, ale wyszczególnia zadania, które należy przepracować. Wymagają one aktywności ze strony osoby doświadczającej straty, jak i wsparcia osób towarzyszących, żałoba jest bowiem procesem, który nie powinien być przeżywany w samotności ${ }^{19}$. Zadania te powinny być przepracowywane jedno po drugim, aby człowiek w kolejnym etapie życia znowu mógł być twórczy. Nie ma bowiem takiej fazy życia, w której człowiek nie jest twórczy, a jeżeli osoba zrezygnowała z twórczości, z tworzenia siebie, to się „zestarzała” w znaczeniu biblijnym (duchowo): jeżeli jesteśmy podobni do Boga, stworzeni na Jego „obraz i podobieństwo" (Rdz 1,26-27), to także w tym sensie, że kształtujemy rzeczywistość w sobie i wokół siebie. Ktoś, kto przestaje być twórczy, oddalił się od swojego Pierwowzoru.

Wracając do modelu przepracowania straty - Worden identyfikuje kolejno następujące po sobie zadania:

- akceptacja rzeczywistości związanej ze stratą (przyjęcie realności utraty, uwolnienie się od naturalnego buntu wobec utarty cennej wartości), rozpoczęcie procesu żałoby. Jest to do-

18 Zob.J. W. Worden, Grief counselling and grief therapy, London 1983. Koncepcja ta została przyjęta m.in. przez: M. Keirse, Smutek, strata, żałoba. Jak sobie z nimi radzić? Jak pomóc innym?, tłum. M. Wężowska, Radom 2004, s. 25-41. Autor pisał o stracie w postaci śmierci osoby bliskiej, wydaje się jednak, że koncepcja zachowuje aktualność także w przypadku innych strat znaczących.

${ }_{19}$ Ten wątek wart jest podjęcia w kontekście starości, ale ponieważ nie mieści się w ramach niniejszego przyczynku, zostanie opracowany w oddzielnym tekście. Szeroko bada tę problematykę cytowana już L. Kroll. 
świadczenie szczególnie bolesne, ale konieczne do inicjacji „,procesu zdrowienia". Akceptacja faktu przemijania, choroby ma dynamizm uwalniający negatywne emocje, które tłumione, mogą zatruć całe emocjonalno-duchowe wnętrze człowieka, czyniąc z niego „emocjonalne monstrum”. Podobnie szkodliwe może być pielęgnowanie doznanych krzywd, które nie zostały przepracowane. Jak długo się tylko buntuję, tak długo nie nastąpiło rzeczywiste uświadomienie sobie straty, czyli konfrontacja z zadaniem do wykonania;

- świadome przeżycie oraz wyrażenie wszystkich u c zuć związanych ze stratą, zwłaszcza doświadczenie bólu, uporządkowanie swojej relacji do wartości utraconej. Na tej płaszczyźnie szczególnie mocno dochodzi do głosu komunikacja ludzi starych z środowiskiem życia, z bliskimi. Smutne i szkodliwe jest, kiedy - jak w piosence Edyty Geppert - „zostają sami z landrynkami”, a jeśli z wnukami, to na zdjęciach. Jeżeli są partnerzy do rozmowy, to każda, nawet najtrudniejsza emocja może być rozbrojona, każda trudna rzeczywistość może stać się bardziej przyjazna (taką rolę pełnią przecież spotkania z terapeutami). Sposób wyrażania tych emocji jest często gwałtowny, mało dyplomatyczny, impulsywny, ale przecież nie chodzi w tym przypadku o okrągłe zdania, lecz o otwarcie bolącej duszy. Jeżeli tego „uwolnienia” zabraknie, następuje kumulacja i wzmocnienie negatywnego postrzegania rzeczywistości, własnego życia;

- przystosowanie się do rzeczywistości bez dóbr znaczących, które utracono w procesie starzenia się. Chodzi o zobaczenie realnego horyzontu własnego życia w tej fazie, w której jestem. Ponieważ jest to proces trudny i trafiający w najczulsze obszary naszej emocjonalności, nierzadko próbujemy stosować uniki, sztucznie meblując swoją codzienność, np. nadmiarem pracy, wielością zobowiązań. Ucieczka nie jest jednak rzeczywistą konfrontacją z powagą życia. Starość ma swoje nieubłagane realia, które trzeba zobaczyć i w nich się odnaleźć;

- otwa rcie się na świat i ludzi, pokochanie życia na nowo.

Spotkanie z pogodnymi seniorami pokazuje ich bogactwo, życiowe doświadczenie, a przede wszystkim wewnętrzny pokój z sobą (i z Bogiem). 


\section{ks. Piotr Morciniec}

Swoistym sprawdzianem owocnego przepracowania strat związanych z wejściem w starość jest „siła przyciągania” młodych i ludzi w sile wieku, którzy w takich przypadkach garną się do osoby starej. Wtedy mamy piękną starość, która oznacza, że osoba przeżyła proces „oddawania swojej młodości" i konstruuje nową teraźniejszość. Tworzenie swojej nowej rzeczywistości przez seniora jest udaniem się w drogę w stronę mądrości.

\section{W stronę mądrości i owocowania}

Powyżej w tytule mowa jest o skierowaniu się w stronę mądrości, a więc o p ro ce s i e, który wydaje się ważniejszy niżjego skutek. Różne są drogi zdobywania mądrości. Najlepsze wskazuje, oczywiście, Pismo Święte - dość przywołać choćby najkrótszą z dróg, opisaną w Psalmie 23, 1-4a:

Pan jest moim pasterzem, nie brak mi niczego. Pozwala mi leżeć na zielonych pastwiskach. Prowadzi mnie nad wody, gdzie mogę odpocząć: orzeźwia moją duszę. Wiedzie mnie po właściwych ścieżkach przez wzgląd na swoje imię. Chociażbym chodził ciemną doliną, zła się nie ulęknę, bo Ty jesteś ze mną.

Nie ulega wątpliwości, że wymiary religijny i duchowy wprowadzają nową jakość w problematykę właściwego przeżywania starości. Jeżeli ludzie starzy odkryją perspektywę religijną dla swojego życia, to jest to dla nich wielka pomoc w konstruowaniu swojej przyszłości, jeżeli natomiast pozostaną na poziomie świeckim, to także potrzebują czegoś, co zaspokoi ich pragnienie sensu. Kiedy się znajdę w owej „ciemnej dolinie” - w trudnej fazie życia, jaką niewątpliwie jest starość - co jako człowiek mam do dyspozycji? Otóż „przechodzenie przez ciemną dolinę” czasu strat, czyli starości, pozwala odkrywać nowe powołanie życiowe w ostatniej kwarcie życia. Rzadko, niestety, za rzadko mówi się i podkreśla prawdę, że człowiek w każdej fazie życia ma swoje nowe powołanie. Nie ma takiej fazy życia, w której człowiek nie jest do czegoś wezwany, i byłoby obrazą Boga stwierdzenie czy przekonanie, że osoba jest w jakimś momencie swojego życia bezużyteczna, niepotrzebna. Problem polega na tym, że ludzie starsi dość często tej prawdy nie odkryli, bo albo nie zadali sobie trudu pytania o sens swojego bycia tu i teraz, albo poddali się 
tej przedmiotowej perspektywie, kiedy coś się z nimi dzieje bez ich podmiotowego zaangażowania.

Poprawnie zadane pytanie brzmi: Jakie jest moje zadanie życiowe na ten etap mojej egzystencji ${ }^{20}$. Nie jest prawdą redukcja starości do fazy czekania na śmierć. Taka faza byłaby pomyłką. Można tęsknić za przejściem, a raczej za „,powrotem do domu Ojca”, jak to nazwał św. Jan Paweł II, bo tęsknota ma potencjał twórczy, w przeciwieństwie do czekania na unicestwienie. Codzienność dostarcza wielu przykładów seniorów, którzy oswoili rzeczywistość i nadali jej nowy, twórczy sens ${ }^{21}$. Nadanie sensu starości, mojej starości, jest nadrzędnym powołaniem na ostatnią kwartę życia. Wydaje się, że najsensowniejsza jest starość „przeżywana dla”, czyli w duchu proegzystencji. Wielu chorych i cierpiących ofiarowuje swoje cierpienie za innych, „niesie swój krzyż codzienności" w duchu ekspiacji za zło, w łączności z cierpieniami Chrystusa ${ }^{22}$. Ciekawym skądinąd zagadnieniem jest problem, czy różnorakie ograniczenia i cierpienia związane ze starością mogę potraktować jako „obdarowanie ze strony Boga”, a więc narzędzie dalszego świadczenia dobra, skoro każdy dar jest równocześnie zadaniem. Niewątpliwie natomiast odkrywanie tego, co w danej fazie życia jest swoiście moim powołaniem, jest ważniejsze nawet niż owocowanie, czyli niż skutki, które to zaangażowanie przyniesie. Droga jest ważniejsza niż cel, do którego prowadzi. Starość jest drogą, drogą odkrywania wciąż na nowo tego celu, którym ma być owocowanie.

Twórczego opisu starości jako drogi mądrości i owocowania dokonał jeden z najaktywniejszych seniorów świata, papież Franciszek, człowiek zaskakująco młody duchem i wzorcowo twórczy. Takie postacie jak św. Matka Teresa z Kalkuty, św. Jan Paweł II - zwłaszcza z ostatnich lat swo-

20 Odpowiedzi mogą być rożne. Nie brakuje psychologów, którzy wiążą jakość starości z osobowością samego seniora - według wyróżnionych typów (omówienie np.: J. Dziedzic, Das Alter - ein Problem oder eine Chance? Versuch einer multiperspektivischen pastoralen Reflexion, dz. cyt., s. 36-37), wydaje się jednak, że poprzestanie na tym czynniku zubożyłoby integralność ujęcia problemu.

${ }^{21} \quad$ Z tej perspektywy sparaliżowana staruszka bywa bardziej twórcza niż niejeden dbający o kondycję emeryt.

22 Ten wieloraki sens inspirująco opisał Jan Paweł II w Liście apostolskim Salvifici doloris z 1984 roku. 
jego pontyfikatu i choćby ze spotkań z młodymi, których porywał mimo swoich chorobowych ograniczeń, zadając kłam tezie, jakoby młodzi akceptowali tylko sukces - czy papież Franciszek pokazują, że człowiek stary może być skarbem, bogactwem owocowania. Po ludzku przegrany Jan Paweł II przemawiał jeszcze mocniej niż we wcześniejszych latach, a wymowa jego świadectwa była nie do odparcia.

Otóż papież Franciszek w przemówieniu do kardynałów bezpośrednio po swoim wyborze na Stolicę Piotrową powiedział m.in.:

Być może połowa z nas jest ludźmi w podeszłym wieku. Starość - lubię tak to określać - jest siedzibą mądrości życia. Starcy posiadają mądrość zdobytą w przeciągu całego życia, jak starzec Symeon czy prorokini Anna w Świątyni Jerozolimskiej, i towłaśnieta mądrość pozwoliła im rozpoznać Jezusa. Dawajmy tę mądrość ludziom młodym, jak dobre wino, które z biegiem lat staje się lepsze! Dawajmy młodym mądrość życia! Przychodzi mi na myśl to, co pewien niemiecki poeta mówił o starości: „Es ist ruhig, das Alter, und fromm”: s ta rość jest czasem spokoju i modlitwy. Trzeba młodym dawać tę mądrość ${ }^{3}$ [podkreśl. P.M.].

Najistotniejsze papieskie obrazy dla starości jako czasu owocowania są następujące:

- źródło mądrości życia, która przejawia się w odkryciu wymiaru nadprzyrodzonego, więcej: w rozpoznaniu i poznaniu osobowego Boga w Jezusie Chrystusie. Mądrość jest więc owocem wieloletniego dojrzewania, ale jej istota jest jedna - nadprzyrodzona. Jeżeli senior nie odkryje wymiaru nadprzyrodzonego, to jest to starość w jakieś mierze zagubiona, a bilans życia bywa smutny ${ }^{24}$;

- owoce ze swojej natury są narzędziem obdarowania, inaczej się zmarnują i zbutwieją - stąd istotą dojrzałej mądrości jest wyjście do innych, zwłaszcza tych, którzy - co naturalne - jeszcze mądrości nie mają, czyli do młodych. Wskazując różne formy obdarowania, Jan Paweł II pisał: „W jakże wielu rodzinach wnuki

23 Franciszek do kardynałów, 15.03.2013, www.ekai.pl/wydarzenia/temat_dnia/x64710/ franciszek-do-kardynalow/ (18.03.2013).

${ }^{24}$ Zdarza się czasem u końca życia usłyszeć czyjeś wyznanie: „zmarnowałem (am) życie”. To jest bilans ludzkiej tragedii, życia, które nie nabrało sensu. 
poznają podstawy wiary dzięki dziadkom!"25. Osoby starsze, które zamykają się na innych, muszą zostać zdiagnozowane jako takie, które nie podjęły procesu przepracowania strat związanych z przemijaniem, co zaowocowało antyowocami;

- mądrość życia właściwie definiuje hierarchię wartości, tzn. ob d a rowuje spokojem i stawia na dialog, szczególnietennadprzyrodzony. Nie oznacza to jednak, że starcy, którzy nie odkryli jeszcze swojego miejsca przy Chrystusie, są od tego zadania wolni, wręcz przeciwnie: zanurzając się w milczeniu, spokoju, uczą się rozmowy, tej najgłębszej: o sensie i celu życia człowieka, o wieczności. Zwłaszcza ostatni z obrazów przekonuje, że nie ma takiego czasu, który nie byłby odpowiedni do wejścia w rolę ucznia Chrystusa. I ta rola jest rozstrzygająca zarówno w duszpasterstwie, jak i w osobistym kształtowaniu swojego życia.

\section{Zamiast zakończenia}

Żeby nie pozostać wyłącznie na płaszczyźnie teorii i w obszarze religijno-duchowym, chciałbym na koniec przywołać praktyczną próbę wprowadzenia w życie tego, co nazwałbym twórczym prze żywaniem s ta r ó c i. Chodzi o rolę, jaką wyznaczono najstarszemu pokoleniu w programie Specjalnej Strefy Demograficznej (SSD) na Opolszczyźnie, gdzie na co dzień żyję i pracuję. Pierwsza wątpliwość, która nasuwa się od razu, to poszukiwanie związku poprawy sytuacji demograficznej z seniorami. Wielu niezorientowanym wydaje się, że rozwiązania demograficzne mają jeden cel - zwiększyć dzietność populacji, a cały wysiłek powinien być nakierowany bezpośrednio na ten skutek. Okazuje się jednak, że społecznie dzieci nie da się „zamówić”, stąd potrzeba odmiennego, bardziej dalekowzrocznego podejścia. I właśnie tu plasuje się istota nowego podejścia do osób starszych.

Graficznie rozwiązanie systemowe wypracowane dla SSD przez Urząd Marszałkowski Województwa Opolskiego przedstawia rysunek 1.

25 Jan Paweł II, List Do moich Braci i Sióstr..., 13. 


\section{PAKIETY PROGRAMU SPECJALNEJ STREFY DEMOGRAFICZNEJ W WOJEWÓDZTWIE OPOLSKIM}

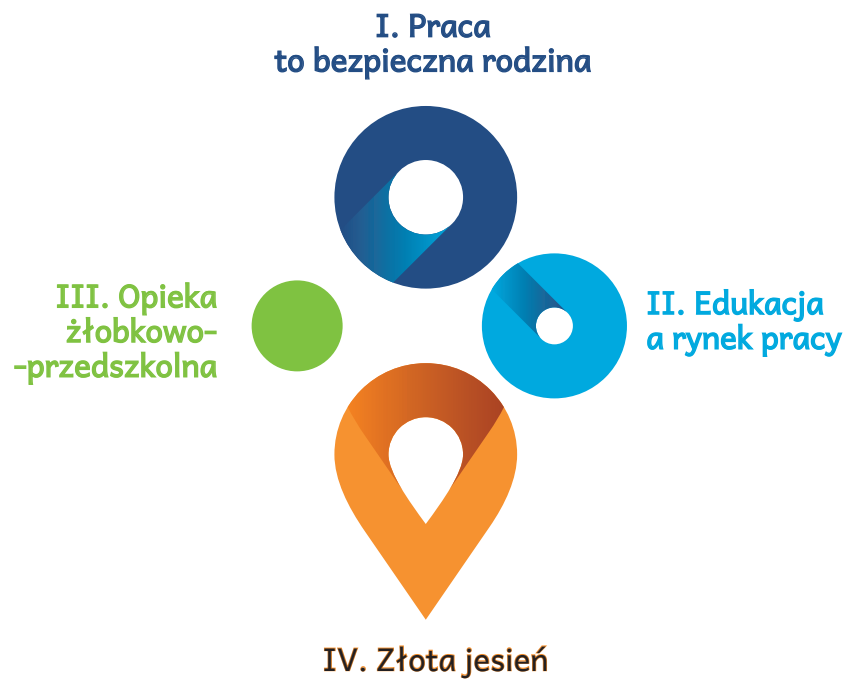

Rys. 1. Pakiety Programu SSD na Opolszczyźnie

Źródło: http://ssd.opolskie.pl/page/201,logo-ssd.html (4.06.2014).

Wyjaśnienie projektu jest następujące: Widać tzw. sygnet: symbolicznego ludzika, za którym tęsknimy, czyli nowe pokolenie. Mocną stroną tego ludzika jest stabilna podstawa, którą są seniorzy. Skąd się wzięło takie rozumowanie? Seniorzy są silną podstawą przede wszystkim dlatego, że są gwarantami wartości i doświadczenia życiowego oraz dlatego, że mamy ich na Opolszczyźnie najwięcej. Cechy, które w ramach programu przypisano seniorom, to dojrzałość, doświadczenie i spokój. Jeżeli w ramach programu nie będziemy współpracować z najliczniejszą grupą społeczną, jesteśmy skazani na porażkę. Nawet taka czysto socjologiczna obserwacja podnosi range grupy ludzi starszych.

Konsekwencje takiego postrzegania ludzi starych w programie SSD przedstawiają się następująco: liczebność grupy senioralnej oznacza naj- 
pierw rosnącą liczbę miejsc pracy w opiece nad nimi. Akcent pada jednak na ośrodki pobytu dziennego, świetlice tematyczne oraz różne formy działalności hobbystycznej (wypracowano nowy profil zawodowy dla osób bezrobotnych: animator osób starszych), ale także generowanie nowych form kształcenia dla młodych w obszarze opieki geriatrycznej i paliatywnej.

Po drugie z potencjału seniorów można i trzeba skorzystać. Są bowiem nie tylko liczni, lecz także coraz dłużej sprawni, w wielu wypadkach zaangażowani. Pojawia się więc pomysł lepszego, bardziej zinstytucjonalizowanego i zorganizowanego wykorzystania ich mobilności w opiece nad dziećmi, co może ułatwić potencjalnym rodzicom decyzję o rodzicielstwie bez konieczności długofalowej rezygnacji z pracy. Po trzecie rosnąca liczba seniorów ma także wymiar komercyjny, ponieważ stanowią oni dużą grupę nabywców, którzy powiększają ekonomiczny kapitał regionu. Do nich także trzeba dopasować nową ofertę usług i produktów.

Program demograficzny dotyczący przyszłości i młodych, zogniskowany na przyszłych pokoleniach nie tylko zauważa ludzi starych, ale czyni z nich jedno z centralnych ogniw naprawczych. To, czego nie wolno w nim pominąć, to bezcenna wartość integracji międzypokoleniowej, integracja seniorów z dziećmi. Jeżeli starsze pokolenie jest ostoją wartości, to tak fundamentalne wartości jak miłość, rodzina, rodzicielstwo, życie ludzkie muszą zostać o nie oparte. Przy takim spojrzeniu podmiotowość seniora jest na wagę złota, bo w wymiarze społecznym nie dokona się nic wielkiego, jeśli zabraknie osobistego zaangażowania ludzi starych. Wybór własnej drogi, rozwinięcie własnej podmiotowości przez seniorów otwiera tym samym lepsze perspektywy całemu społeczeństwu, co dobrze współgra z tenorem nauczania Kościoła adresowanego do ludzi starych. Ludzie starzy są bowiem fundamentem społeczeństwa, nie jego marginesem. Taka świadomość pozwala godnie przeżywać własną starość, bo przecież bez fundamentu każda budowla - także społeczeństwo - się zawali. 


\section{ks. Piotr Morciniec}

\section{Summary}

\section{Getting old with dignity: from experiencing loss to fruition}

The practice of life and the literature on the subject strike us as antagonistic, firmly positive or negative understanding of old age. The first one most often has biblical and theological roots, whereas the other one - sociocultural ones. Searching for the proper attitude towards our own and someone else's old age we find out that the senior time as the time of discovering a new sense can only be chosen, not sententiously recommended or demanded. The major point of the text is that the failure at shaping the sense of own old age results mainly from not working out the losses associated with this stage of life. To show the way to respectable old age, the author tried to define the actual state of so called old age or senior age (1), then he discussed the issue of working out the diagnosed real and subjective losses (2) so as to, in the course of the process, reach the point of reaping the fruits of life and old age (3) and introducing the trial of practical accomplishment of the approach (4).

Keywords: getting old, human dignity, pastoral care, Church and the aging

\section{Starzeć się z godnością: od doświadczenia straty do owocowania}

W praktyce życia i w literaturze przedmiotu uderza antagonistyczne, stanowczo pozytywne lub negatywne ujmowanie starości. Pierwsze ma najczęściej korzenie biblijno-teologiczne, drugie - socjokulturowe. Szukając właściwej postawy wobec własnej i cudzej starości, odkrywamy, że okres senioralny jako czas odnajdywania nowego sensu można tylko w y b r a ć, nie da się go natomiast moralizatorsko zalecić lub nakazać. Główna teza tekstu brzmi, że niepowodzenia w kształtowaniu sensu własnej starości wynikają w dużej mierze z nieprzepracowania strat wiążących się z tą fazą życia. W celu wskazania drogi do godnej starości starano się najpierw zdefiniować stan faktyczny zwany starością czy wiekiem senioralnym (1), następnie omówiono zagadnienie przepracowania zdiagnozowanych strat rzeczywistych i subiektywnych (2), by w trakcie tego celowego procesu dojść do zbierania owoców życia i starości (3) i do przybliżenia próby praktycznej realizacji takiego podejścia (4).

Słowa kluczowe: starzenie się, godność ludzka, opieka duszpasterska, Kościół i starsi

\section{Bibliografia}

Ancyparowicz G., Kapitałowe emerytury i renty a ryzyko ubóstwa w Polsce, [w:] Rządowa Rada Ludnościowa, O sytuacji ludzi starszych, red.J. Hrynkiewicz, Warszawa 2012, s. 83-97.

Die Deutschen Bischöfe, Tote begraben und Trauernde trösten. Bestattungskultur im Wandel aus katholischer Sicht, Bonn 2005. 
Dziedzic J., Das Alter - ein Problem oder eine Chance? Versuch einer multiperspektivischen pastoralen Reflexion, „Analecta Cracoviensia” 43 (2011), s. 25-41.

Franciszek do kardynałów, 15.03.2013, www.ekai.pl/wydarzenia/temat_dnia/x64710/ franciszek-do-kardynalow/ (18.03.2013).

Gabriel K., Jaeger W., Hoff G. M., Alter und Altern als Herausforderung, Freiburg i. Br. 2011.

Grzywocz K., Jak przeżyć stratę, „Zeszyty Formacji Duchowej” (2004) 24, s. 29-37.

Jan Paweł II, List Do moich Braci i Sióstr - ludzi w podeszłym wieku, Watykan 1.10.1999.

Kast V., Kryzys jest szansa, czyli jak wykorzystać trudności, tłum. R. Zajączkowski, Kielce 2001.

Kast V., Sich einlassen und loslassen, Freiburg i. Br. 1994.

Keirse M., Smutek, strata, żałoba. Jak sobie z nimi radzić? Jak pomóc innym?, tłum. M. Wężowska, Radom 2004.

Kroll L., Towarzyszenie w żałobie jako postulat etyczny. Studium teologicznomoralne, mps, Opole 2006.

Laslett P., Das dritte Alter, München 1995.

Ochberg F. M., Post-traumatic therapy and victims of violence, New York 1988.

Paul Ch., Wie kann ich mit meiner Trauer leben?, Gütersloh 2000.

Pikuła N., Etos starości w aspekcie społecznym, Kraków 2011.

Psychologiczne aspekty śmierci, umierania iżałoby, red. W. Badura-Madej, Kraków 1993.

Virt G., Die Bedeutung der Ethikberatung für einschlägige EU-regelungen. Zur Rolle des theologischen Ethikers in einem säkularisierten Europa, Laibach 2013, mps.

Virt G., Sich auf das Alter einstellen solange noch Zeit ist, „Family Forum” 2001, t. I, s. 179-192.

Worden J. W., Grief counselling and grief therapy, London 1983. 